\title{
Responses of plant community to the linkages in plant-soil $C: N: P$ stoichiometry during secondary succession of abandoned farmlands, China
}

\author{
LIU Weichao ${ }^{1,2}$, FU Shuyue ${ }^{1,2}$, YAN Shengji ${ }^{1}$, REN Chengjie ${ }^{1,2}$, WU Shaojun ${ }^{1,2}$, DENG Jian ${ }^{3}$, \\ LI Boyong $^{1}$, HAN Xinhui ${ }^{1,2^{*}}$, YANG Gaihe ${ }^{1,2}$ \\ ${ }^{1}$ College of Agronomy, Northwest A\&F University, Yangling 712100, China; \\ ${ }^{2}$ Research Center of Recycle Agricultural Engineering and Technology of Shaanxi Province, Yangling 712100, China; \\ ${ }^{3}$ School of Life Science, Yan'an University, Yan'an 716000, China
}

\begin{abstract}
Succession is one of the central themes of ecology; however, the relationship between aboveground plant communities and underground soils during secondary succession remains unclear. In this study, we investigated the composition of plant community, plant-soil C:N:P stoichiometry and their relationships during secondary succession after the abandonment of farmlands for $0,10,20,30,40$ and 50 a in China, 2016. Results showed that the composition of plant communities was most diverse in the farmlands after secondary succession for 20 and 50 a. Soil organic carbon and total nitrogen contents slightly decreased after secondary succession for 30 a, but both were significantly higher than those of control farmland (31.21\%-139.10\% and 24.24\%-121.21\%, respectively). Moreover, C:N ratios of soil and microbe greatly contributed to the changes in plant community composition during secondary succession of abandoned farmlands, explaining $35.70 \%$ of the total variation. Particularly, soil C:N ratio was significantly and positively related with the Shannon-Wiener index. This study provides the evidence of synchronous evolution between plant community and soil during secondary succession and C:N ratio is an important linkage between them.
\end{abstract}

Keywords: C:N ratio; soil nutrient; plant community; restoration; loess hilly region

Citation: LIU Weichao, FU Shuyue, YAN Shengji, REN Chengjie, WU Shaojun, DENG Jian, LI Boyong, HAN Xinhui, YANG Gaihe. 2020. Responses of plant community to the linkages in plant-soil C:N:P stoichiometry during secondary succession of abandoned farmlands, China. Journal of Arid Land, 12(2): 215-226. https://doi.org/10.1007/s40333-020-0009-6

\section{Introduction}

During secondary succession, change in soil nutrient availability would affect the structure of plant communities and the level of productivity (Zhang et al., 2018a). Correspondingly, the biomass and nutrient composition of plants, through the return of litter, affect the physical characteristics, nutrient content and microbial composition in soil (Chen and Chen, 2018). This change provides a good template for us to study the process of natural coordinated plant-soil recovery under temporal changes (Zhao et al., 2013). Especially, the ecological stoichiometry that is an important indicator reflecting the carbon $(\mathrm{C})$, nitrogen $(\mathrm{N})$ and phosphorous $(\mathrm{P})$ cycles inside the soil (Zechmeister-Boltenstern et al., 2015) integrates the variability of ecosystem function and

\footnotetext{
*Corresponding author: HAN Xinhui (E-mail: hanxinhui@nwsuaf.edu.cn)

The first and second authors contributed equally to this work.

Received 2019-01-12; revised 2019-12-15; accepted 2020-01-07

(C) Xinjiang Institute of Ecology and Geography, Chinese Academy of Sciences, Science Press and Springer-Verlag GmbH Germany, part of Springer Nature 2020
} 
is widely used in the study of limitative nutrient element determination (Zhou et al., 2018), biogeochemical cycles and population dynamics (Martiny et al., 2016; Busch et al., 2018; Couic et al., 2018). During the process of secondary succession of abandoned farmlands, the relationship between the changes in ecological stoichiometric ratio and the aboveground plant community succession is unknown. Studying this issue will help us to understand the nutrient cycle in the succession of ecosystems and also improve our understanding of the direction and drivers of community restoration.

During natural restoration, plant coverage and community composition significantly change (Zhao et al., 2019). However, there is still debate about how plant community diversity changes. One argument is the classical theory, indicating that the richness continues to increase along the plant succession (Clements, 1936; Margalef, 1963); the other is the intermediate species-richness hypothesis, indicating that the species richness firstly increases, and then decreases during the succession (Bazzaz, 1975). Changes in species diversity are determined by the differences in the community habitats and interspecific relationships (Odum, 1969; Hessen et al., 2004; Hu et al., 2009). Climatic conditions of the loess plateau are the most important factors affecting secondary succession (Ma et al., 2018). For example, nutrient poverty and water limitation on the loess plateau limit the development of plant community. However, the pattern of soil nutrients' accumulation and its mechanisms are not well understood during secondary succession (Thuille and Schulze, 2006), which poses an obstacle to our study on the synergistic recovery of plant and soil. Therefore, we hypothesized that changes in soil and plant may be unified with more intrinsic factors, such as the C:N:P stoichiometric ratio and microbial regulation (Bonanomi et al., 2005). Plants fix carbon through photosynthesis, absorb nitrogen from soil through the rhizosphere and mycorrhiza, adapt to their nutrient needs and maintain a certain $\mathrm{C}: \mathrm{N}$ ratio. In turn, soil and microorganisms are fed back through litter. C:N ratio reflects plant growth capacity, embodies the key process of soil and plant nutrient exchange and return, and affects the accumulation and stoichiometric ratio of nutrients in plant and soil (Luo et al., 2004).

The growth of plants is often limited by soil nutrients, especially $\mathrm{N}$ and $\mathrm{P}$ contents (Elser et al., 2003). Limited nutrients significantly influence the composition and development of plant community. For example, Ning et al. (2017) found that legumes in N-deficient soils had a growth advantage. Therefore, the balance of soil nutrients affects the interspecific competition of plants, and then affects the succession of community. Microbe plays a subtle role between soil and plant (Wall and Moore, 1999). The leguminous rhizobium that is symbiotic with leguminous plants, converts nitrogen from air to feed the plants, but microbe and plant also compete for nutrients in barren soil (Ning et al., 2017). As the most active factor in soil, microorganisms are the main factor of soil nutrient transformation (Liang et al., 2017). They absorb nutrients from the soil and return to the soil after synthesis and transformation. Microbe determines the effectiveness of nutrients in the soil and is linked to the use of nutrients by aboveground plants. Hence, microorganisms regulate the relationship between soil and plant. Thus, we can speculate that $\mathrm{C}: \mathrm{N}: \mathrm{P}$ stoichiometric ratios of soil and plant are closely related to the characteristics of plant community, and different plants have diverse adaptations to nutrient ratios.

The loess hilly region of China is one of the areas with the most severe soil erosion and desertification. Coupled with climate drought, the ecological environment is very fragile (Yao et al., 2013). In order to restore the ecology and prevent soil erosion, there is a series of projects implemented, such as the "Grain for Green" project, which has greatly improved the local ecological environment ( $\mathrm{Liu}$ and $\mathrm{Fu}, 2013$ ). More than $9.26 \times 10^{6} \mathrm{hm}^{2}$ farmlands had been converted into forests or grasslands from 1999 to 2010 (Zhang et al., 2013). This conversion provides a good template to understand the fundamental ecological patterns and processes of biotic communities during secondary succession. Previous studies have shown that soil nutrients and plant characteristics significantly changed during secondary succession. However, there are still controversies about the changing characteristics and complex relationships between soil and plant, which is an obstacle to our understanding of the coordinated restoration of soil-plant during 
secondary succession. Therefore, this study focused on (1) the synergetic restoration of plant-soil-microbe nutrients, and (2) the relationship between plant community and C:N:P stoichiometric ratio during secondary succession. The results would give us a new perspective on the relationship between plant and soil. The aims of this study are to explore: (1) the synergistic changes in plant-soil-microbe nutrient and $\mathrm{C}: \mathrm{N}: \mathrm{P}$ stoichiometric ratio during secondary succession after abandonment, (2) the changes in composition and characteristics of plant community, and (3) the effect of $\mathrm{C}: \mathrm{N}: \mathrm{P}$ stoichiometric ratio on plant community.

\section{Materials and methods}

\subsection{Study area}

The study area is located in the Wuliwan Catchment of Ansai District of Yan'an City, Shaanxi Province $\left(36.86^{\circ}-36.88^{\circ} \mathrm{N}, 109.33^{\circ}-109.77^{\circ} \mathrm{E}\right)$, which is in the hinterland of the Chinese Loess Plateau. As the Calcaric Cambisol (Food and Agriculture Organization of the united nation, FAO) soil is loose, soil erosion forms hilly ravines. The study area belongs to arid and semi-arid zone. The mean annual precipitation is $510.0 \mathrm{~mm}$, the annual mean temperature is $8.8^{\circ} \mathrm{C}$, and the climate is hot and rainy in summer and cold and dry in winter. Since 1999, the Chinese government has carried out the project named "Grain for Green". Thus, the most widely used method for rehabilitating the vegetation of this region is to convert farmlands with slopes greater than $25^{\circ}$ into grasslands or forestlands. In addition, there are still some arable lands that have been abandoned by farmers because of low productivity and naturally being turned into grasslands.

\subsection{Experimental design and vegetation investigation}

The experiment was conducted in July 2016. Five types of grasslands with different restored ages were selected (10, 20, 30, 40 and 50 a), and one farmland planting millet (Setaria italica) was used as a control. All information of studied sites is shown in Table 1. All sites are located in the same area, elevation, slope and aspect. Before being abandoned, grasslands were similar in terms of farming measures, mainly planting soybeans (Glycine max) and millet. Three replicated plots were set for each stage of succession. The distance between two plots exceeded the spatial correlation $(<13.5 \mathrm{~m})$ of most soil variables (Marriott et al., 1997). To make an investigation of the plants, we selected five $1 \mathrm{~m} \times 1 \mathrm{~m}$ squares for each plot to investigate the species, number, height and coverage of the plants (Zhao et al., 2015). The aboveground parts of the plants were cut off to measure the soil organic carbon (SOC), $\mathrm{N}$ and $\mathrm{P}$ contents after drying at $60^{\circ} \mathrm{C}$.

Table 1 Information of farmland with different restored ages

\begin{tabular}{|c|c|c|c|c|c|c|}
\hline Parameter & FL & AL10 & AL20 & AL30 & AL40 & AL50 \\
\hline Location & $\begin{array}{l}36.86^{\circ} \mathrm{N}, \\
109.35^{\circ} \mathrm{E}\end{array}$ & $\begin{array}{l}36.73^{\circ} \mathrm{N}, \\
109.28^{\circ} \mathrm{E}\end{array}$ & $\begin{array}{l}36.76^{\circ} \mathrm{N}, \\
109.27^{\circ} \mathrm{E}\end{array}$ & $\begin{array}{l}36.74^{\circ} \mathrm{N}, \\
109.28^{\circ} \mathrm{E}\end{array}$ & $\begin{array}{l}36.76^{\circ} \mathrm{N}, \\
109.28^{\circ} \mathrm{E}\end{array}$ & $\begin{array}{l}36.74^{\circ} \mathrm{N}, \\
109.28^{\circ} \mathrm{E}\end{array}$ \\
\hline Elevation (m) & 1205.40 & 1239.10 & 1095.60 & 1290.80 & 1103.10 & 1251.20 \\
\hline Slope aspect $\left(^{\circ}\right)$ & - & 290 & 200 & 319 & 70 & 237 \\
\hline $\mathrm{pH}$ & $8.55 \pm 0.11^{\mathrm{a}}$ & $8.59 \pm 0.05^{\mathrm{a}}$ & $8.62 \pm 0.02^{\mathrm{a}}$ & $8.56 \pm 0.04^{\mathrm{a}}$ & $8.58 \pm 0.05^{\mathrm{a}}$ & $8.50 \pm 0.03^{\mathrm{a}}$ \\
\hline $\mathrm{BD}\left(\mathrm{g} / \mathrm{cm}^{3}\right)$ & $1.26 \pm 0.03^{\mathrm{a}}$ & $1.04 \pm 0.01^{\mathrm{b}}$ & $1.02 \pm 0.01^{\mathrm{b}}$ & $1.07 \pm 0.06^{\mathrm{a}}$ & $1.08 \pm 0.03^{\mathrm{b}}$ & $1.06 \pm 0.03^{\mathrm{b}}$ \\
\hline SMC (\%) & $9.05 \pm 0.38^{\mathrm{c}}$ & $9.29 \pm 0.49^{\mathrm{c}}$ & $14.18 \pm 0.31^{\mathrm{a}}$ & $9.60 \pm 0.20^{\mathrm{c}}$ & $11.57 \pm 0.15^{\mathrm{b}}$ & $10.78 \pm 0.02^{\mathrm{b}}$ \\
\hline $\begin{array}{l}\text { Dominant } \\
\text { species }\end{array}$ & Setaria italica & $\begin{array}{l}\text { Setaria } \\
\text { viridis }\end{array}$ & $\begin{array}{c}\text { Stipa } \\
\text { grandis }+ \\
\text { Artemisia } \\
\text { melinii }\end{array}$ & $\begin{array}{c}\text { Setaria } \\
\text { viridis }+ \\
\text { Roegneria } \\
\text { kamoji }\end{array}$ & $\begin{array}{l}\text { Artemisia } \\
\text { gmelinii }+ \\
\text { Lespedeza } \\
\text { floribunda }\end{array}$ & $\begin{array}{l}\text { Artemisia } \\
\text { gmelinii }\end{array}$ \\
\hline $\begin{array}{c}\text { Shannon-Wiener } \\
\text { index }\end{array}$ & - & $1.84 \pm 0.06^{\mathrm{c}}$ & $2.41 \pm 0.02^{\mathrm{ab}}$ & $2.12 \pm 0.16^{\mathrm{bc}}$ & $2.27 \pm 0.13^{\mathrm{ab}}$ & $2.58 \pm 0.02^{\mathrm{a}}$ \\
\hline Margalef index & - & $3.20 \pm 0.18^{\mathrm{b}}$ & $3.96 \pm 0.24^{\mathrm{a}}$ & $3.27 \pm 0.06^{\mathrm{ab}}$ & $2.99 \pm 0.30^{\mathrm{b}}$ & $3.64 \pm 0.21^{\mathrm{ab}}$ \\
\hline
\end{tabular}

Note: BD, bulk density; SMC, soil moisture content; FL, farmland; AL10, AL20, AL30, AL40 and AL50 mean abandoned farmlands for 10, 20, 30, 40 and 50 a, respectively. The abbreviations are the same as in Tables 2 and 3. Different lowercase letters indicate significant difference among grasslands with different restored ages and farmland at $P<0.05$ level. - means no value. Mean \pm SD. 


\subsection{Soil sampling}

When soil was sampled, the surface humus layer was first removed and then the upper $10 \mathrm{~cm}$ of soil was taken with a soil auger $(10 \mathrm{~cm}$ in diameter). Ten "S" shaped replicates were taken from each site and mixed evenly. After being passed through a 2-mm sieve, $500 \mathrm{~g}$ of soil was mixed as a sample. Each sample was sealed and sent back to the lab using a low temperature refrigerator. All soils were quickly brought back to the lab and divided into two parts. One part was stored at $-20^{\circ} \mathrm{C}$ to determine the biological properties of soil such as microbial biomass and enzyme activities. Another part was stored at the room temperature (about $25^{\circ} \mathrm{C}$ ) to determine the soil physical-chemical properties.

\subsection{Analyses of plant and soil physical-chemical properties}

Plant was dried to a constant weight at $60^{\circ} \mathrm{C}$ and was used to determine the SOC, $\mathrm{N}$ and $\mathrm{P}$ contents after grinding. SOC was measured using the $\mathrm{K}_{2} \mathrm{Cr}_{2} \mathrm{O}_{7}$ oxidation method. $\mathrm{N}$ content was measured using the Kjeldahl method (Zhang et al., 2019). P content was measured using the colorimetric (UV-spectrophotometer) method after digestion with $\mathrm{H}_{2} \mathrm{SO}_{4}-\mathrm{H}_{2} \mathrm{O}_{2} . \mathrm{C}, \mathrm{N}$ and $\mathrm{P}$ contents of the microbe were measured in the soil fumigated with chloroform (Brookes et al., 1985; Vance et al., 1987). The soil was dried at $105^{\circ} \mathrm{C}$ for $24 \mathrm{~h}$ to determine the bulk density (BD) (Vos et al., 2005). Soil $\mathrm{pH}$ was measured by a $\mathrm{pH}$ meter after shaking a soil-water suspension $(1: 5 \mathrm{w} / \mathrm{v})$ for $30 \mathrm{~min}$. The difference value in the mass of soil sample before and after drying at $105^{\circ} \mathrm{C}$ was used to determine the soil moisture content (SMC).

\subsection{Data analyses}

Godron's method of judging the stability of plant communities was originally applied to industrial production (Godron et al., 1971). Zheng (2000) improved this method and made it more widely used. This approach takes into account the interspecific relationships and species distribution of the community. The species number and individual number comprehensively represent the characteristics of the plant community, which is linked to the developmental stage and stability of the plant community. The relative frequencies of the plant species within the quadrat were ranked in diminishing order, and a smooth curve was established using the cumulative values. This curve intersects the line $x+y=100$ at one point. The Euclidean distance between this intersection and point $20 / 80$ indicates the proximity degree of the actual community to the stable community. Godron (1971) stated that plant community is the most stable when $20 \%$ species accumulate to $80 \%$ relative frequencies. Therefore, the smaller the Euclidean distance, the more stable the community.

In all 15 grassland plots, a total of 69 plants were investigated. The distribution of plants within each plot is listed in Table 2. Important value (IV, \%) for each species was calculated using the following formula:

$$
\mathrm{IV}=1 / 4 \text { (relative height }+ \text { relative coverage }+ \text { relative frequency }+ \text { relative density). }
$$

The Shannon-Wiener and Margalef indices were calculated using the following formulas:

$$
\begin{gathered}
\text { Shannon }- \text { Wiener index }=-\sum_{i=1}^{s}\left(P_{i} \ln P_{i}\right), \\
\text { Margalef index }=(S-1) / \ln N,
\end{gathered}
$$

where $P_{i}$ is the important value of the $i^{\text {th }}$ species in a quadrat; $S$ is the species number in a quadrat; and $N$ is the total number of plants.

Based on the distribution of IV of plant community, we generated a non-metric multidimensional scaling (NMDS) plot using the CANOCO 4.5 software package to assess the clustering of the plant community according to the changes of years. Redundancy analysis (RDA) was performed using the CANOCO 4.5 software package, which reflects the relationship between plant community composition and environmental factors (plant-soil-microbe $\mathrm{C}: \mathrm{N}: \mathrm{P}$ stoichiometric ratios). We performed spearman correlation analysis using SPSS 20.0 in order to investigate the linkage of soil property and $\mathrm{C}: \mathrm{N}: \mathrm{P}$ stoichiometric ratio. In addition, changes in the community characteristics, soil physical properties, plant-soil-microbe $\mathrm{C}, \mathrm{N}$ and $\mathrm{P}$ contents, stoichiometric ratio, Shannon-Wiener index, Margalef index and Euclidean distance induced by abandoned ages were tested via one-way ANOVA (analysis of variance) using the $\mathrm{R}$ package. 


\section{Results}

\subsection{Changes in plant community and soil property}

As the secondary succession preceded, soil property was improved and plant community varied dramatically (Table 1). The soil $\mathrm{pH}$ did not significantly differ among six plots. Soil BD of farmland was significantly $(16.7 \%-23.5 \%)$ higher than those of grasslands. SMC of grasslands increased by $2.6 \%-56.7 \%$ more than that of farmland, and the differences were statistically significant.

Changes in the Margalef index and Shannon-Wiener index were fluctuant with restored ages and showed increased, reduced and then increased trends. Euclidean distances representing for the community stability varied from 24.72 to 27.79 , suggesting that the community was unstable. The dominated species in the five abandoned farmlands are Setaria viridis, Stipa grandis+Artemisia gmelinii, Setaria viridis+Roegneria kamoji, Artemisia gmelinii+Lespedeza floribunda and Artemisia gmelinii (Tables 1 and 2). A total of 69 plant species were identified in the abandoned farmlands, belonging to 20 families, among which Gramineae, Compositae and Leguminosae were the three largest families. After succession for 50 a, the community translated from the pioneer of Gramineae to Leguminosae+Asteraceae gradually and formed a fairly stable climax community of Artemisia gmelinii after succession for 40 a.

For plant community, sampling plots were distant from each other and were greatly affected by the ages of abandonment. For example, the aggregation degree of abandoned farmlands for 10 a was distant from that of abandoned farmlands for 30 a and both of them were very distant from those of abandoned farmlands for 20, 40 and 50 a (Fig. 1).

Table 2 Changes of important value in different plant families and farmlands with different abandoned ages

\begin{tabular}{|c|c|c|c|c|c|}
\hline Family & AL10 & AL20 & AL30 & AL40 & AL50 \\
\hline Valerianaceae & 0.00 & 5.23 & 0.00 & 0.00 & 1.23 \\
\hline Labiatae & 0.28 & 0.00 & 3.53 & 1.07 & 1.74 \\
\hline Euphorbiaceae & 4.21 & 0.00 & 1.82 & 0.00 & 0.00 \\
\hline Leguminosae & 12.86 & 17.13 & 6.54 & 26.80 & 18.95 \\
\hline Gramineae & 55.91 & 25.39 & 59.77 & 16.51 & 28.90 \\
\hline Violaceae & 0.00 & 2.65 & 0.00 & 2.60 & 0.27 \\
\hline Compositae & 10.21 & 32.20 & 16.53 & 27.07 & 39.87 \\
\hline Chenopodiaceae & 2.25 & 0.00 & 6.21 & 0.45 & 0.00 \\
\hline Orobanchaceae & 0.00 & 0.00 & 0.00 & 0.00 & 0.70 \\
\hline Asclepiadaceae & 0.00 & 0.00 & 0.00 & 5.87 & 0.00 \\
\hline Geraniaceae & 6.36 & 0.47 & 0.63 & 0.00 & 0.00 \\
\hline Ranunculaceae & 0.00 & 0.80 & 0.00 & 1.35 & 0.00 \\
\hline Rubiaceae & 0.00 & 0.00 & 0.00 & 0.00 & 0.65 \\
\hline Rosaceae & 0.00 & 7.24 & 0.00 & 8.04 & 5.96 \\
\hline Umbelliferae & 0.00 & 1.72 & 0.00 & 0.00 & 0.80 \\
\hline Cyperaceae & 0.00 & 5.75 & 0.00 & 8.98 & 0.24 \\
\hline Cruciferae & 0.99 & 0.00 & 2.80 & 0.64 & 0.00 \\
\hline Convolvulaceae & 2.19 & 0.00 & 0.00 & 0.00 & 0.00 \\
\hline Polygalaceae & 0.00 & 1.42 & 0.64 & 0.63 & 0.71 \\
\hline Bignoniaceae & 4.73 & 0.00 & 1.52 & 0.00 & 0.00 \\
\hline
\end{tabular}




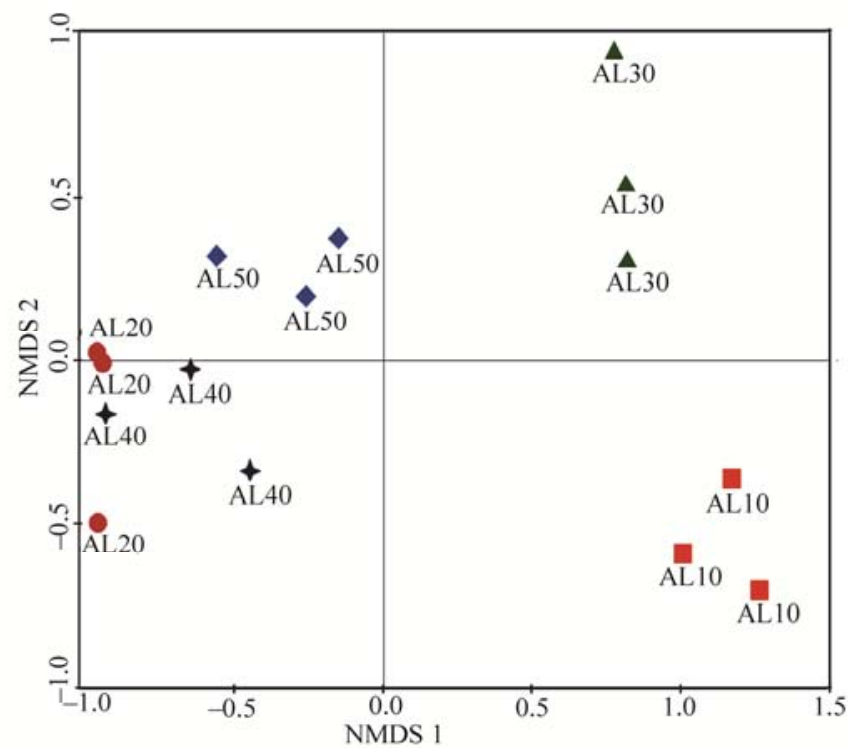

Fig. 1 Plant community comparisons by nonmetric multidimensional scaling (NMDS) analysis plots based on the Bray-Curtis dissimilarity under farmlands with different abandoned ages. AL10, AL20, AL30, AL40 and AL50 mean abandoned farmlands for 10, 20,30,40 and 50 a, respectively.

\subsection{Changes in plant-soil C:N:P stoichiometry}

3.2.1 $\mathrm{C}, \mathrm{N}$ and $\mathrm{P}$ contents in plant and soil

There was a significant relationship between recovery time and SOC, N and P contents of the soil and microbial community (Table 3 ). In the plant, $\mathrm{C}$ and $\mathrm{N}$ contents in the abandoned farmlands for 30 a were significantly higher than those of the other abandoned farmlands for 10, 20, 40 and 50 a by $13.26 \%-24.19 \%$ and $30.60 \%-164.76 \%$, respectively, and slightly declined in the abandoned farmlands for 40 and 50 a, while plant $\mathrm{P}$ content in the abandoned farmlands for $30 \mathrm{a}$ was significantly lower than those of the other abandoned farmlands for 10, 20, 40 and 50 a by $26.77 \%-44.09 \%$. In the soil, SOC and N contents in the abandoned farmlands were significantly higher than those of the control farmland, and were the highest in the abandoned farmlands for $30 \mathrm{a}$, while soil P content slowly increased but did not change significantly. C, N, and P contents of microbe in the abandoned farmlands significantly increased compared with those of the control farmland, and significantly increased with increasing ages of abandonment, except that $\mathrm{N}$ content peaked in the abandoned farmlands for $30 \mathrm{a}$.

Table 3 C, N and P contents in plant, soil and microbe

\begin{tabular}{|c|c|c|c|c|c|c|}
\hline Parameter & FL & AL10 & AL20 & AL30 & AL40 & AL50 \\
\hline Plant C (g/kg) & $0.00 \pm 0.00$ & $356.29 \pm 16.40^{b}$ & $385.65 \pm 6.72^{\mathrm{ab}}$ & $422.47 \pm 14.88^{\mathrm{a}}$ & $390.66 \pm 9.26^{\mathrm{ab}}$ & $381.78 \pm 11.88^{\mathrm{ab}}$ \\
\hline Plant N (g/kg) & $0.00 \pm 0.00$ & $10.92 \pm 0.60^{\mathrm{c}}$ & $10.54 \pm 0.45^{\mathrm{c}}$ & $17.37 \pm 0.25^{\mathrm{a}}$ & $13.30 \pm 1.20^{\mathrm{b}}$ & $6.56 \pm 0.51^{\mathrm{d}}$ \\
\hline Plant P (g/kg) & $0.00 \pm 0.00$ & $1.83 \pm 0.10^{\mathrm{a}}$ & $1.61 \pm 0.07^{\mathrm{a}}$ & $1.27 \pm 0.01^{\mathrm{b}}$ & $1.81 \pm 0.11^{\mathrm{a}}$ & $1.71 \pm 0.01^{\mathrm{a}}$ \\
\hline $\mathrm{SOC}(\mathrm{g} / \mathrm{kg})$ & $2.98 \pm 0.05^{\mathrm{e}}$ & $3.91 \pm 0.19^{\mathrm{d}}$ & $4.11 \pm 0.10^{\mathrm{cd}}$ & $5.35 \pm 0.16^{\mathrm{a}}$ & $4.89 \pm 0.08^{b}$ & $4.31 \pm 0.08^{\mathrm{c}}$ \\
\hline Soil N (g/kg) & $0.33 \pm 0.01^{\mathrm{e}}$ & $0.41 \pm 0.02^{\mathrm{d}}$ & $0.50 \pm 0.03^{\mathrm{d}}$ & $0.73 \pm 0.03^{\mathrm{a}}$ & $0.62 \pm 0.01^{\mathrm{b}}$ & $0.59 \pm 0.01^{\mathrm{b}}$ \\
\hline Soil P (g/kg) & $0.46 \pm 0.02^{\mathrm{a}}$ & $0.52 \pm 0.03^{\mathrm{a}}$ & $0.49 \pm 0.05^{\mathrm{a}}$ & $0.51 \pm 0.04^{\mathrm{a}}$ & $0.52 \pm 0.03^{\mathrm{a}}$ & $0.56 \pm 0.02^{\mathrm{a}}$ \\
\hline Microbe C (mg/kg) & $71.69 \pm 2.61^{\mathrm{d}}$ & $103.94 \pm 8.76^{\mathrm{c}}$ & $123.35 \pm 6.08^{\mathrm{c}}$ & $171.41 \pm 6.38^{\mathrm{b}}$ & $194.78 \pm 5.36^{\mathrm{a}}$ & $195.98 \pm 9.01^{\mathrm{a}}$ \\
\hline Microbe N (mg/kg) & $10.82 \pm 0.10^{\mathrm{e}}$ & $13.82 \pm 0.88^{\mathrm{c}}$ & $16.84 \pm 0.88^{\mathrm{c}}$ & $23.90 \pm 0.99^{\mathrm{a}}$ & $21.48 \pm 0.58^{\mathrm{b}}$ & $17.42 \pm 0.55^{\mathrm{d}}$ \\
\hline Microbe P (mg/kg) & $4.90 \pm 0.18^{\mathrm{c}}$ & $7.75 \pm 0.92^{\mathrm{b}}$ & $7.93 \pm 0.49^{b}$ & $8.29 \pm 0.37^{\mathrm{b}}$ & $9.07 \pm 0.39^{\mathrm{ab}}$ & $10.64 \pm 0.72^{\mathrm{a}}$ \\
\hline
\end{tabular}

Note: C, carbon; N, nitrogen; P, phosphorus; SOC, soil organic carbon. Different lowercase letters within the row indicate significant difference among farmlands with different abandoned ages at $P<0.05$ level. Mean $\pm \mathrm{SD}$. 


\subsubsection{C:N:P stoichiometry in plant and soil}

Natural recovery of farmlands greatly affected the C:N, C:P and N:P stoichiometric ratios of soil, microbe and plant (Fig. 2). Soil C:N ratio gradually decreased, while $\mathrm{C}: \mathrm{N}$ ratios of microbe and plant gradually increased. $\mathrm{C}: \mathrm{P}$ and $\mathrm{N}: \mathrm{P}$ ratios in soil, microbe and plant increased at first and subsequently decreased, peaking between 20 and 30 a. Regression analysis on the stoichiometric ratio indicated that microbe and plant had parallel correlativity with soil, which is a negative correlation with the $\mathrm{C}: \mathrm{N}$ ratio and positive correlations with the $\mathrm{C}: \mathrm{P}$ and $\mathrm{N}: \mathrm{P}$ ratios (Fig. 3 ).
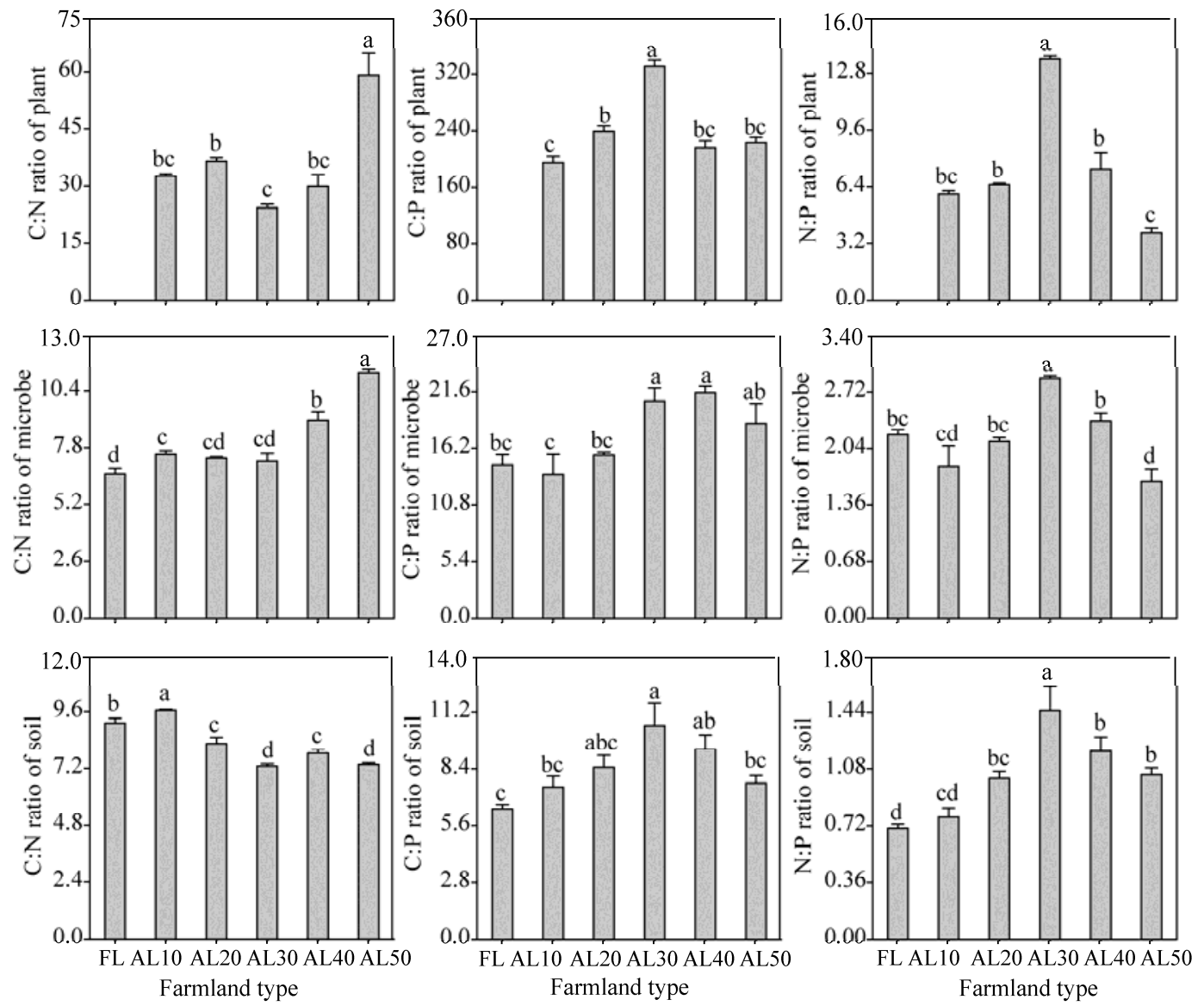

Fig. 2 Plant-microbe-soil C:N:P stoichiometric ratios under farmlands with different abandoned ages. Different lowercase letters indicate significant difference among farmlands with different abandoned ages at $P<0.05$ level. Bars are standard errors. FL, farmland. AL10, AL20, AL30, AL40 and AL50 mean abandoned farmlands for 10, $20,30,40$ and 50 a, respectively.

\subsection{Relationship between plant community and plant-soil C:N:P stoichiometry}

Spearman's rank correlation coefficients between the plant community characteristics (Shannon-Wiener index, Euclidean distance and Margalef index) and C:N:P stoichiometric ratios of plant, soil and microbe showed that the Shannon-Wiener index was significantly and negatively correlated with soil $\mathrm{C}: \mathrm{N}$ and had a significant and positive correlation with the C:N ratios of microbe and plant (Table 4). RDA result showed that $\mathrm{C}: \mathrm{N}: \mathrm{P}$ ratios significantly affected the plant communities, together explaining $80.8 \%$ of the total variation; especially, $\mathrm{C}: \mathrm{N}$ ratios of soil and microbe explained $18.8 \%$ and $16.9 \%$ of the total variation, respectively (Fig. 4). Furthermore, IV of Compositae was positively correlated with $\mathrm{C}: \mathrm{N}$ ratios of plant and microbe, and negatively correlated with $\mathrm{C}: \mathrm{N}$ ratio of soil. 

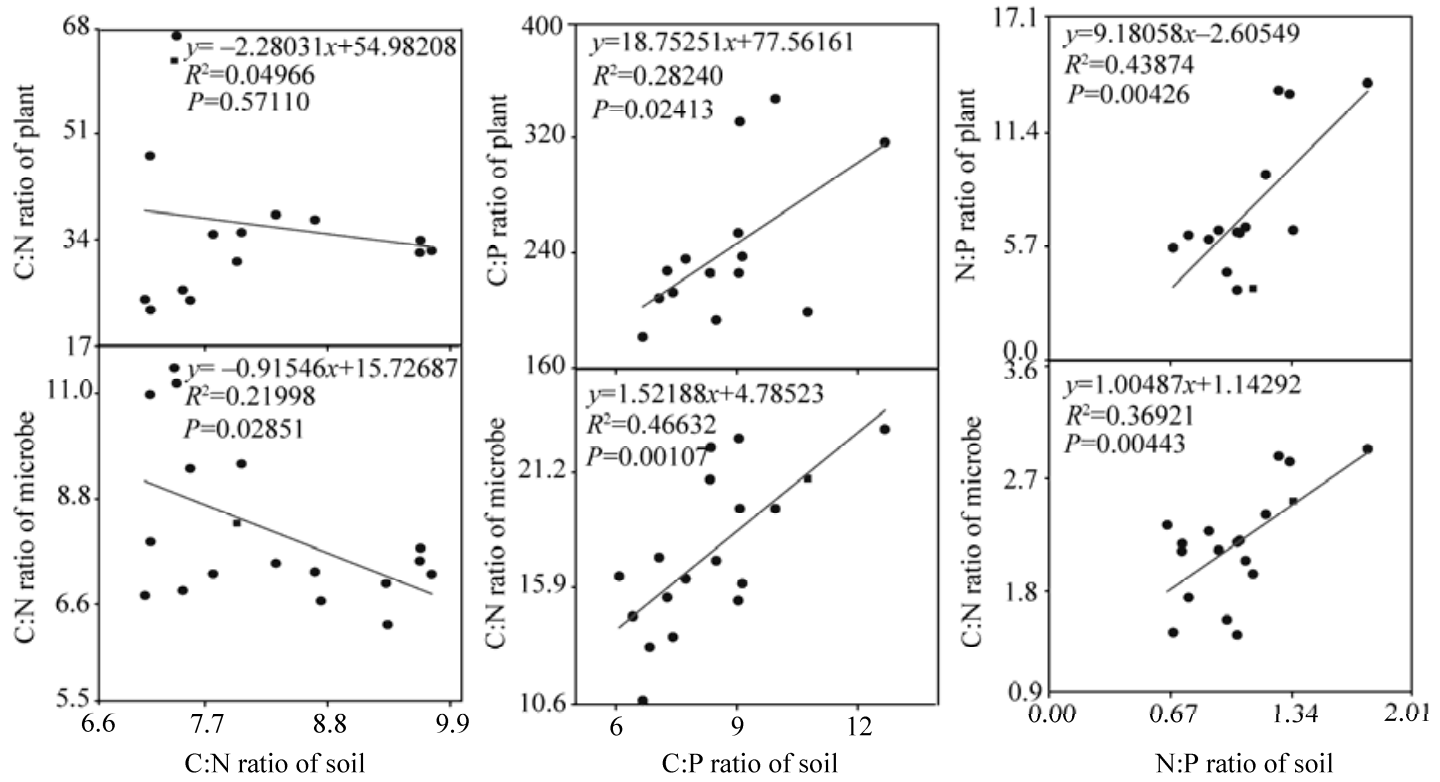

Fig. 3 Relationships among plant-microbe-soil C:N:P stoichiometric ratios

Table 4 Pearson's correlation coefficient between plant diversity index and C:N:P stoichiometry

\begin{tabular}{ccccccc}
\hline Index & $\begin{array}{c}\text { C:N ratio of } \\
\text { soil }\end{array}$ & $\begin{array}{c}\text { C:P ratio of } \\
\text { soil }\end{array}$ & $\begin{array}{c}\mathrm{N}: \mathrm{P} \text { ratio of } \\
\text { soil }\end{array}$ & $\begin{array}{c}\text { C:N ratio of } \\
\text { microbe }\end{array}$ & $\begin{array}{c}\text { C:P ratio } \\
\text { of microbe }\end{array}$ & $\begin{array}{c}\text { N:P ratio of } \\
\text { microbe }\end{array}$ \\
\hline Shannon-Wiener & $-0.552^{*}$ & -0.230 & -0.009 & $0.535^{*}$ & 0.164 & -0.218 \\
Margelef & -0.063 & -0.240 & -0.177 & 0.083 & -0.305 & -0.332 \\
ED & -0.069 & -0.190 & -0.096 & 0.403 & 0.085 & -0.227 \\
\hline
\end{tabular}

Note: ED, Euclidean distance. "indicates significant correlation at $P<0.05$ level (two-tailed).

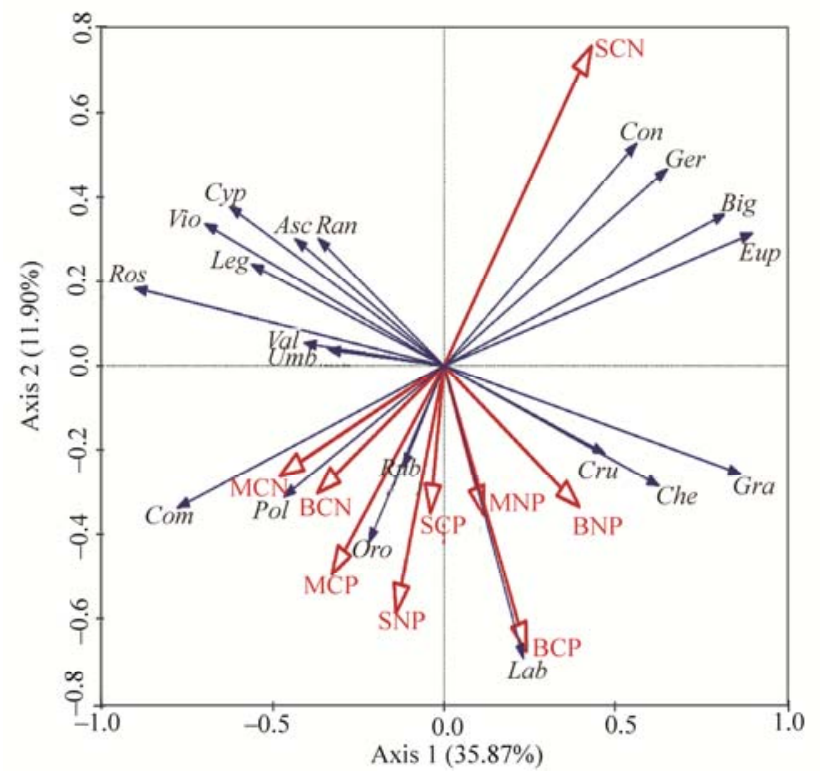

Fig. 4 Redundancy analysis (RDA) ordination biplot of plant communities (blue arrows) and C:N:P stoichiometric ratios (red arrows). $\mathrm{MCN}, \mathrm{C}: \mathrm{N}$ ratio of microbe; $\mathrm{MCP}, \mathrm{C}: \mathrm{P}$ ratio of microbe; $\mathrm{MNP}, \mathrm{N}: \mathrm{P}$ ratio of microbe; $\mathrm{BCN}, \mathrm{C}: \mathrm{N}$ ratio of plant; $\mathrm{BCP}, \mathrm{C}: \mathrm{P}$ ratio of plant; $\mathrm{BNP}, \mathrm{N}: \mathrm{P}$ ratio of plant; $\mathrm{SCN}, \mathrm{SOC}: \mathrm{N}$ ratio of soil; SCP, SOC:P ratio of soil; SNP, N:P ratio of soil; Val, Valerianaceae; Lab, Labiatae; Eup, Euphorbiaceae; Leg, Leguminosae; Gra, Gramineae; Vio, Violaceae; Com, Compositae; Che, Chenopodiaceae; Oro, Orobanchaceae; Asc, Asclepiadaceae; Ger, Geraniaceae; Ran, Ranunculaceae; Rub, Rubiaceae; Ros, Rosaceae; Umb, Umbelliferae; Cyp, Cyperaceae; Cru, Cruciferae; Con, Convolvulaceae; Pol, Polygalaceae; Big, Bignoniaceae. 


\section{Discussion}

\subsection{Linkages of plant-soil C:N:P stoichiometry during secondary succession of abandoned farmlands}

Different succession stages resulted in differences in the distribution of plant-soil-microbe C, N, and $\mathrm{P}$ contents within the ecosystem (Zechmeister-Boltenstern et al., 2016). This difference was reflected in the stoichiometric ratio of each component (Zhang et al., 2018b). The secondary succession of abandoned farmland resulted in significant increases in the $\mathrm{C}, \mathrm{N}$ and $\mathrm{P}$ contents of various parts of the ecosystem, indicating that nutrients were accumulated as the succession proceeded. However, nutrient $(\mathrm{C}$ and $\mathrm{N})$ contents of soil and plant peaked after 30 a of recovery and slightly decreased in the later stage, which may be related to the absolute superiority of the later stage of succession. In addition, trend of soil moisture firstly increased and then decreased, just like that of nutrients, indicating that the changes of soil moisture and nutrients were synergistic. For example, some studies have mentioned that the increase of soil moisture can significantly improve the activity of microorganisms, thereby promoting the transfer of soil nutrients by microorganisms and improving the accumulation of soil nutrients (Cruz-Martinez et al., 2012; Liang et al., 2017). The changes of soil moisture and nutrients affect the developmental direction of plant community. During the transition period from grass to shrub community, annual plants were gradually replaced by perennials, nutrients in the ecosystem were transferred to plants, and nutrient contents in soil were slightly reduced.

Regression fitting analysis of soil-plant $\mathrm{C}: \mathrm{N}: \mathrm{P}$ stoichiometric ratios showed that plant and microbe had parallel correlations with soil, which were negative for $\mathrm{C}: \mathrm{N}$ ratio and positive for $\mathrm{C}: \mathrm{P}$ and $\mathrm{N}: \mathrm{P}$ ratios. In the grassland ecosystem, accumulation of $\mathrm{C}$ mainly comes from plant photosynthesis, that of $\mathrm{N}$ comes from microbial nitrogen fixation and wet deposition, and that of $\mathrm{P}$ mainly comes from rock weathering. Therefore, variation in $\mathrm{P}$ content is not significant. $\mathrm{C}$ and $\mathrm{N}$ contents significantly contributed to the variation in ecological stoichiometry. During secondary succession process, $\mathrm{C}: \mathrm{N}$ ratio is more reflective of the relationship between soil and biological groups (plant and microbe). In this study, soil $\mathrm{C}: \mathrm{N}$ ratio showed a decreasing trend with the restored ages, which is due to the higher accumulation rate of $\mathrm{N}$ than that of $\mathrm{C}$. Furthermore, $\mathrm{C}: \mathrm{N}$ ratio is lower than the average level in China (10.1-12.1) (Wang, 2008). The lower C:N ratio indicates a faster decomposition rate of minerals into the soil and a shorter cycle of nutrients, which may be related to the superior adaptability of grass in the ecosystem (Erktan et al., 2016). However, it also indicates a poor soil C sequestration capacity (Sterner and Elser, 2002). This may be due to the previous soil erosion and degradation, which had seriously damaged $\mathrm{C}$ and $\mathrm{N}$ cycles. Plant and microbe had parallel correlations with the soil C:N:P stoichiometric ratio, implying that biological groups in the ecosystem had underlying relationships with active nutrient acquisition (Jaeger et al., 1999; Grigulis et al., 2013). For example, C sequestration capacity of plant and microbe gradually increased with the age of abandonment, i.e., the amount of carbon fixed per unit of nitrogen increased (Ratnam et al., 2008). Therefore, during secondary succession of abandoned farmlands, nutrient use efficiency of plant communities continuously improved.

\subsection{Effects of plant-soil C:N:P stoichiometry on plant community}

Composition of plant communities of abandoned farmlands is dramatically related to the time series (Fig. 1). The overall increase trend was observed in terms of the diversity (Shannon-Wiener index), stability (Euclidean distance), and richness (Margalef index) of plant communities on abandoned farmlands. Climax plant community appeared after the farmland was abandonment for 40 a, and was dominated by Artemisia gmelinii. However, Godron et al. (1971) found that stability index of abandoned farmlands is unstable. This implies that the climate in the loess hilly region is a constraint on the succession of grass community (Wang et al., 2009; Han et al., 2010), which might be further replaced by the shrub community. Especially in the Chinese Loess Plateau, soil moisture is the most critical factor in the development of grassland ecosystem (Zhao and $\mathrm{Hu}, 2008$ ). Studies have shown that secondary succession of plant community in the abandoned farmlands underwent the following process, i.e., annual herbaceous was the absolute dominant species, then annual and perennial herbaceous competitively existed, and gradually, shrubs began to appear and became the dominant species. Meanwhile, diversity and richness 
indices of plant community were significantly affected by soil moisture (Tables 1 and 4), which is consistent with the result of Haripal and Sahoo (2011). In addition, the coverage, richness index, diversity and stability were higher after secondary succession for 20 a, indicating that plant community reached a relatively balanced point. Traces of truth can be found from the species composition. After abandonment for 20 a, Compositae and Leguminosae had the highest IV and species richness than those of the other stages; especially Compositae, whose heterogeneity was greater vertically and horizontally and led to the highest diversity. At the later stage of succession, increasing competition among plant species gradually decreased dominant species and community diversity, which is consistent with the hypothesis of Bazzaz (1975) and Rundel (1997).

Soil nutrients have a great influence on community composition and biodiversity (Guo et al., 2018). The improvement and recovery of the soil matrix will inevitably promote the development of biomes (Ren et al., 2016; Ren et al., 2018). Corresponding to the change of plant diversity, the soil and microbial nutrients also showed an increasing trend (Zhang et al., 2016). After abandonment for 20 to 30 a, the contents of $\mathrm{C}$ and $\mathrm{N}$ in plants, soil and microorganisms reached their maximums, while that of $\mathrm{P}$ was modestly improved. This shows that there is a potential synchronous relationship between soil and vegetation restoration. Studies have shown that during secondary succession of abandoned farmlands, there is a relationship between vegetation restoration and soil nutrients that both affect and depend on each other and the dominant driving force gradually changes from soil nutrients to vegetation. This phenomenon also results in that the development of soil often lags behind the change of vegetation characteristics (Jiao et al., 2006). This is consistent with our results (Tables 1 and 3 ). When we try to find the coupling point through the relationships among $\mathrm{C}: \mathrm{N}: \mathrm{P}$ ratios of soil, microbes and plants, we find that the C:N ratio is the decisive factor for the change in plant community and its cumulative contribution percentage reaches $50.6 \%$. Due to the substantial stable source of $\mathrm{P}, \mathrm{C}: \mathrm{N}$ determines the availability and balance of nutrients to microbe in the soil and promotes the nutrient efficiency for plant driven by microbe turnover in the soil. Different plant functional groups have different utilization preferences and efficiency to soil nutrients, and the change in $\mathrm{C}: \mathrm{N}$ in turn drives the changes in plant superiority and diversity. RDA analysis showed that Compositae had positive relationships with microbe $\mathrm{C}: \mathrm{N}$ ratio and biomass $\mathrm{C}: \mathrm{N}$ ratio, and a negative relationship with soil $\mathrm{C}: \mathrm{N}$ ratio (Fig. 6). The accumulation of soil nutrients allows the establishment of the Compositae groups that have a strong allelopathic effect to inhibit the growth of other plants through root exudates (Zhou et al., 2004). Its short and flexible growing cycle and numerous small seeds both establish its advantage over the interspecific competition (Sutherland, 2004; Hao et al., 2009). Thus, during the succession of abandoned farmlands, $\mathrm{C}: \mathrm{N}$ ratio mainly drives the development of Compositae community.

\section{Conclusions}

During secondary succession of abandoned farmlands, the plant-soil-microbe $\mathrm{C}, \mathrm{N}$ and $\mathrm{P}$ contents significantly increased, and the plant community tended to be mature and stable. The plant compositions gradually changed from the Gramineae to the Compositae and Leguminosae. The ecological C:N:P stoichiometry, particularly the $\mathrm{C}: \mathrm{N}$ ratio, is the bond of plant-soil-microbe co-succession. Among those families, the absolutely dominant species of Compositae was positively correlated with the $\mathrm{C}: \mathrm{N}$ ratios of plant and microbe, and negatively correlated with the $\mathrm{C}: \mathrm{N}$ ratio of soil.

\section{Acknowledgements}

This work was funded by the National Natural Science Foundation of China (41877543, 41571501).

\section{References}

Bazzaz F A. 1975. Plant species diversity in old-field successional ecosystems in southern Illinois. Ecology, 56(2): 485-488.

Bonanomi G, Rietkerk M, Dekker S C, et al. 2005. Negative plant-soil feedback and positive species interaction in a herbaceous plant community. Plant Ecology, 181: 269-278. 
Brookes P C, Landman A, Pruden G, et al. 1985. Chloroform fumigation and the release of soil nitrogen: A rapid direct extraction method to measure microbial biomass nitrogen in soil. Soil Biology and Biochemistry, 17(6): 837-842.

Busch V, Klaus V H, Penone C, et al. 2018. Nutrient stoichiometry and land use rather than species richness determine plant functional diversity. Ecology and Evolution, 8(1): 601-616.

Chen X L, Chen H Y. 2018. Global effects of plant litter alterations on soil $\mathrm{CO}_{2}$ to the atmosphere. Global Change Biology, 24(8): 3462-3471.

Clements F E. 1936. Nature and structure of the climax. Journal of Ecology, 24(1): 252-284.

Couic E, Grimaldi M, Alphonse V, et al. 2018. Mercury behaviour and C, N, and P biogeochemical cycles during ecological restoration processes of old mining sites in French Guiana. Environmental Science: Processes and Impacts, 20: 657-672.

Cruz-Martinez K, Rosling A, Zhang Y, et al. 2012. Effect of rainfall-induced soil geochemistry dynamics on grassland soil microbial communities. Applied and Environmental Microbiology, 78(21): 7587-7595.

Vance E D, Brookes P C, Jenkinson D S. 1987. An extraction method for measuring soil microbial biomass C. Soil Biology and Biochemistry, 19: 703-707.

Elser J J, Acharya K, Kyle M, et al. 2003. Growth rate-stoichiometry couplings in diverse biota. Ecology Letters, 6(10): 936-943.

Erktan A, Cecillon L, Graf F, et al. 2016. Increase in soil aggregate stability along a Mediterranean successional gradient in severely eroded gully bed ecosystems: combined effects of soil, root traits and plant community characteristics. Plant and Soil, 398: 121-137.

Godron M, Daget P, Poissonet J, et al. 1971. Some Aspects of Heterogeneity in Grasslands of Cantal. State College: Pennsylvania State University Press, 397-415.

Grigulis K, Lavorel S, Krainer U, et al. 2013. Relative contributions of plant traits and soil microbial properties to mountain grassland ecosystem services. Journal of Ecology, 101(1): 47-57.

Guo S J, Han X H, Li H, et al. 2018. Evaluation of soil quality along two revegetation chronosequences on the loess hilly region of China. Science of the Total Environment, 633: 808-815.

Han F, Miao B L, Guo R Q, et al. 2010. Spatial-temporal evolvement characteristics of climate productivity for the plants on Inner Mongolia desert steppe. Journal of Anhui Agricultural Sciences, 1(5): 76-79. (in Chinese)

Hao J H, Liu Q Q, Qiang S. 2009. Reproductive traits associated with invasiveness in Bidens pilosa (Asteraceae). Chinese Bulletin of Botany, 44(6): 656-665. (in Chinese)

Haripal K, Sahoo S. 2011. Vegetational dynamics in some tropical abandoned rice fields in the western part of Orissa, India. African Journal of Environmental Science and Technology, 5: 37-44.

Hessen D O, Ågren G I, Anderson T R, et al. 2004. Carbon, sequestration in ecosystems: The role of stoichiometry. Ecology, 85(5): 1179-1192.

Hu Y K, Li K H, Gong Y M, et al. 2009. Plant diversity-productivity patterns in the alpine steppe environment of the Central Tianshan Mountains. Journal of Arid Land, 1(1): 43-48.

Jaeger C H, Monson R K, Fisk M C, et al. 1999. Seasonal partitioning of nitrogen by plants and soil microorganisms in an alpine ecosystem. Ecology, 80(6): 1883-1891.

Jiao F, Wen Z M, Jiao J Y, et al. 2006. Reciprocal effects among vegetation, soil moisture and nutrients of cropland to forest and grassland in the loess hilly region. Acta Prataculturae Sinica, 15(2): 79-84. (in Chinese)

Jose Fernandez-Alonso M, Curiel Y J, Kitzler B, et al. 2018. Changes in litter chemistry associated with global change-driven forest succession resulted in time-decoupled responses of soil carbon and nitrogen cycles. Soil Biology and Biochemistry, 120: $200-211$.

Liang C, Schimel J P, Jastrow J D. 2017. The importance of anabolism in microbial control over soil carbon storage. Nature Microbiology, 2(8): 17105.

Liu Y, Fu B J. 2013. Topographical variation of vegetation cover evolution and the impact of land use/cover change in the Loess Plateau. Arid Land Geography, 36(6): 1097-1102. (in Chinese)

Luo Y Q, Su B, Currie W S, et al. 2004. Progressive nitrogen limitation of ecosystem responses to rising atmospheric carbon dioxide. Bioscience, 54(8): 731-739.

Ma J M, Man D Q, Li D L, et al. 2018. Characteristics of vegetation succession and soil moisture in abandoned cropland of arid desert region. Journal of Desert Research, 38(4): 800-807. (in Chinese)

Margalef R. 1963. On certain unifying principles in ecology. American Naturalist, 97: 357-374.

Marriott C A, Hudson G, Hamilton D, et al. 1997. Spatial variability of soil total C and N and their stable isotopes in an upland Scottish grassland. Plant and Soil, 196(1): 151-162.

Martiny A C, Talarmin A, Mouginot C, et al. 2016. Biogeochemical interactions control a temporal succession in the elemental composition of marine communities. Limnology and Oceanography, 61(2): 531-542.

Ning Z Y, Li Y L, Yang H L, et al. 2017. Carbon, nitrogen and phosphorus stoichiometry in leaves and fine roots of dominant 
plants in Horqin Sandy Land. Chinese Journal of Plant Ecology, 41(10): 1069-1080. (in Chinese)

Odum E P. 1969. The strategy of ecosystem development. Science, 164(3877): 262-270.

Ratnam J, Sankaran M, Hanan N P, et al. 2008. Nutrient resorption patterns of plant functional groups in a tropical savanna: variation and functional significance. Oecologia, 157: 141-151.

Ren C J, Kang D, Wu J P, et al. 2016. Temporal variation in soil enzyme activities after afforestation in the Loess Plateau, China. Geoderma, 282: 103-111.

Ren C J, Chen J, Lu X J, et al. 2018. Responses of soil total microbial biomass and community compositions to rainfall reductions. Soil Biology and Biochemistry, 116: 4-10.

Rundel P W. 1997. Plants in changing environments: Linking physiological, population and community ecology. Tree Physiology, 17(7): 489-489.

Sterner R W, Elser J J. 2002. Ecological Stoichiometry: the Biology of Elements from Molecules to the Biosphere. Princeton: Princeton University Press, 46-54.

Sutherland S. 2004. What makes a weed a weed: life history traits of native and exotic plants in the USA. Oecologia, 141: 24-39.

Thuille A, Schulze E D. 2006. Carbon dynamics in successional and afforested spruce stands in Thuringia and the Alps. Global Change Biology, 12(2): 325-342.

Vance E D, Brookes P C, Jenkinson D S. 1987. An extraction method for measuring soil microbial biomass C. Soil Biology and Biochemistry, 19(6): 703-707.

Vos B D, Meirvenne M V, Quataert P, et al. 2005. Predictive quality of pedotransfer functions for estimating bulk density of forest soils. Soil Science Society of America Journal, 69(2): 500-510.

Wall D H, Moore J C. 1999. Interactions underground: Soil biodiversity, mutualism, and ecosystem processes. Bioscience, 49(2): 109-117.

Wang S Q, Yu G R. 2008. Ecological stoichiometry characteristics of ecosystem carbon, nitrogen and phosphorus elements. Acta Ecologica Sinica, 28(8): 3937-3947. (in Chinese)

Wang X N, Xiang J P, Zhao T N, et al. 2009. A study of vegetation succession in the loess hill and gully area of western Shanxi Province. Bulletin of Soil and Water Conservation, 23(3): 103-107. (in Chinese)

Yao Y B, Wang R Y, Yang J H, et al. 2013. Changes in terrestrial surface dry and wet conditions on the Loess Plateau (China) during the last half century. Journal of Arid Land, 5(1): 15-24.

Zechmeister-Boltenstern S, Keiblinger K M, Mooshammer M, et al. 2015. The application of ecological stoichiometry to plant-microbial-soil organic matter transformations. Ecological Monographs, 85(2): 133-155.

Zhang C, Liu G B, Xue S, et al. 2016. Soil bacterial community dynamics reflect changes in plant community and soil properties during the secondary succession of abandoned farmland in the Loess Plateau. Soil Biology and Biochemistry, 97: 40-49.

Zhang W, Ren C J, Deng J, et al. 2018a. Plant functional composition and species diversity affect soil C, N, and P during secondary succession of abandoned farmland on the Loess Plateau. Ecological Engineering, 122: 91-99.

Zhang W, Gao D X, Chen Z X, et al. 2018b. Substrate quality and soil environmental conditions predict litter decomposition and drive soil nutrient dynamics following afforestation on the Loess Plateau of China. Geoderma, 325: 152-161.

Zhang W, Liu W C, Xu M P, et al. 2019. Response of forest growth to C:N:P stoichiometry in plants and soils during Robinia pseudoacacia afforestation on the Loess Plateau, China. Geoderma, 337: 280-289.

Zhao F Z, Kang D, Han X H, et al. 2015. Soil stoichiometry and carbon storage in long-term afforestation soil affected by understory vegetation diversity. Ecological Engineering, 74: 415-422.

Zhao F Z, Ren C J, Han X H, et al. 2018. Changes of soil microbial and enzyme activities are linked to soil C, N and P stoichiometry in afforested ecosystems. Forest Ecology and Management, 427: 289-295.

Zhao F Z, Bai L, Wang J Y, et al. 2019. Change in soil bacterial community during secondary succession depend on plant and soil characteristics. Catena, 173: 246-252.

Zhao G, Mu X, Wen Z, et al. 2013. Soil erosion, conservation, and eco-environment changes in the Loess Plateau of China. Land Degradation and Development, 24(5): 499-510.

Zhao Y Y, Hu X. 2008. Review on mechanism of succession of degenerating meadow community during resuming process in Loess Plateau. Research of Soil and Water Conservation, 15(6): 274-276. (in Chinese)

Zheng Y R. 2000. Comparison of methods for studying stability of forest community. Scientia Silvae Sinicae, 36(5): 28-32. (in Chinese)

Zhou K, Guo W M, Xu Y C. 2004. Advances of research on allelopathic potential in Compositae. Acta Ecologica Sinica, 24(8): 1776-1784. (in Chinese)

Zhou Y, Boutton T W, Wu X B. 2018. Soil phosphorus does not keep pace with soil carbon and nitrogen accumulation following woody encroachment. Global Change Biology, 24(5): 1992-2007. 